\title{
Luteimonas lutimaris sp. nov., isolated from a tidal flat
}

\author{
Youn-Je Park, ${ }^{1}$ Moon Su Park, ${ }^{2}$ Seung Hyeon Lee, ${ }^{2}$ Woojun Park, ${ }^{3}$ \\ Kangseok Lee ${ }^{2}$ and Che Ok Jeon ${ }^{2}$ \\ ${ }^{1}$ Department of Applied Bioscience, CHA University, Seoul 135-081, Republic of Korea \\ ${ }^{2}$ Department of Life Science \& Research Center for Biomolecules and Biosystems, \\ Chung-Ang University, Seoul 156-756, Republic of Korea \\ ${ }^{3}$ Division of Environmental Science and Ecological Engineering, Korea University, \\ Seoul 136-701, Republic of Korea
}

Correspondence

Che Ok Jeon

cojeon@cau.ac.kr

A Gram-staining-negative, strictly aerobic bacterium, designated strain $\mathrm{G}^{\top}{ }^{\top}$, was isolated from a tidal flat of the Taean coast in South Korea. Cells were moderately halotolerant and non-motile rods showing catalase- and oxidase-positive reactions. Growth of strain $\mathrm{G}^{\top}{ }^{\top}$ was observed between 15 and $40{ }^{\circ} \mathrm{C}$ (optimum $30{ }^{\circ} \mathrm{C}$ ) and between $\mathrm{pH} 5.5$ and 9.0 (optimum $\mathrm{pH} 6.5-7.5$ ). Strain $G 3^{\top}$ contained $Q-8$ as the predominant lipoquinone and iso- $C_{15: 0}$, iso- $C_{17: 1} \omega 9 c$, iso- $\mathrm{C}_{16: 0}$ and iso- $\mathrm{C}_{11: 0}$ as the major fatty acids. The $\mathrm{G}+\mathrm{C}$ content of the genomic DNA was $69.6 \mathrm{~mol} \%$. Phylogenetic analyses based on 16S rRNA gene sequences showed that strain $\mathrm{G}^{\top}$ formed a tight phylogenetic lineage with Luteimonas mephitis $B 1953 / 27.1^{\top}$ within the genus Luteimonas and was most closely related to L. mephitis B1953/27.1 ${ }^{\top}$ with $98.0 \% 16 \mathrm{~S}$ rRNA gene sequence similarity. The DNA-DNA relatedness between strain $\mathrm{G}^{\top}$ and $L$. mephitis $\mathrm{B} 1953 / 27.1^{\top}$ was $35.2 \pm 3.3 \%$. On the basis of chemotaxonomic data and molecular properties, strain $\mathrm{G} 3^{\top}$ represents a novel species of the genus Luteimonas, for which the name Luteimonas lutimaris sp. nov. is proposed. The type strain is G3 ${ }^{\top}\left(=\operatorname{KACC} 14929^{\top}=J C M 16916^{\top}\right)$.

The genus Luteimonas, a member of the family Xanthomonadaceae of the Gammaproteobacteria, was first proposed by Finkmann et al. (2000) with a single species, Luteimonas mephitis, isolated from a biofilter. This genus is closely related phylogenetically to the genera Lysobacter, Xanthomonas, Pseudoxanthomonas and Stenotrophomonas, which share some characteristics such as the presence of branched-chain fatty acids and ubiquinone-8 (Q-8). Currently, the genus Luteimonas comprises only six recognized species, L. mephitis (Finkmann et al., 2000), L. aestuarii (Roh et al., 2008), L. aquatica (Chou et al., 2008), L. composti (Young et al., 2007), L. marina (Baik et al., 2008) and L. terricola (Zhang et al., 2010), but they have been isolated from diverse habitats such as a biofilter, tidal flat, fresh water, food waste and soil. The western and southern coastal seashores of the Korean peninsula consist of sea tidal flats, known as getbol in Korea, which are unique marine habitats alternately undergoing flooding with seawater and exposure to the atmosphere, and they contain valuable biological resources such as micro-organisms and marine animals. Therefore, efforts have

The GenBank/EMBL/DDBJ accession number for the 16S rRNA gene sequence of strain $\mathrm{G}^{\top}$ is GU199001.

A supplementary figure and a supplementary table are available with the online version of this paper. been made in our laboratory to isolate and characterize members of the bacterial community from tidal flats of the Yellow Sea in South Korea (Kim et al., 2010a, c; Lee et al., 2011). Here, we describe the taxonomic characterization of one more novel Luteimonas species isolated from a tidal flat, for which the name Luteimonas lutimaris sp. nov. is proposed.

Strain $\mathrm{G} 3^{\mathrm{T}}$ was isolated from a tidal flat of the Taean coast of the Yellow Sea, South Korea, using a previously described procedure with some modifications (Kim et al., 2008). Briefly, a tidal flat sample was serially diluted with $0.85 \%$ (w/v) saline, spread on marine agar 2216 (MA; Difco) plates and incubated at $25{ }^{\circ} \mathrm{C}$ for 5 days. PCR amplifications of $16 \mathrm{~S}$ rRNA genes from representative colonies were performed using the universal primers F1 (5'-AGAGTTTGATCMTGGCTCAG-3') and R13 (5'-TACGGYTACCTTGTTACGACTT-3') as described previously ( $\mathrm{Lu}$ et al., 2006). The amplicons were analysed on the basis of restriction fragment length polymorphism (RFLP) after their HaeIII and HhaI double digestion with some modifications of a previously described procedure (Kim et al., 2010b). All representative amplicons with unique RFLP patterns were partially sequenced with the F1 primer and the resulting $16 \mathrm{~S}$ rRNA gene sequences were analysed using the BLAST program (http://www.ncbi.nlm.nih.gov/ 
BLAST/) in GenBank. From the analysis, a novel strain belonging to the genus Luteimonas, designated strain $\mathrm{G} 3^{\mathrm{T}}$, was selected, and its 16S rRNA gene was cloned into the pCR2.1 vector using a TOPO cloning kit (Invitrogen) according to the manufacturer's instructions for more complete sequencing.

Strain $\mathrm{G} 3^{\mathrm{T}}$ was routinely grown aerobically on MA at $30{ }^{\circ} \mathrm{C}$ for 3 days, except where indicated otherwise. The strain was stored at $-80{ }^{\circ} \mathrm{C}$ in marine broth (MB; Difco) supplemented with $10 \%(\mathrm{v} / \mathrm{v})$ glycerol for preservation. Luteimonas mephitis KACC $11391^{\mathrm{T}}$, Luteimonas aestuarii KCTC $22048^{\mathrm{T}}$ and Luteimonas aquatica LMG $24212^{\mathrm{T}}$ were used as reference strains for DNA-DNA hybridization, phenotypic characterization and fatty acid analysis: L. mephitis KACC $11391^{\mathrm{T}}$ was provided by the KACC (Korea) and L. aestuarii KCTC $22048^{\mathrm{T}}$ and L. aquatica $\mathrm{LMG} 24212^{\mathrm{T}}$ were purchased from the KCTC (Korea) and the BCCM/LMG (Belgium), respectively.

The 16S rRNA gene sequence (1467 nt) of strain $\mathrm{G} 3^{\mathrm{T}}$ was compared with available 16S rRNA gene sequences from GenBank using the BLAST program (http://www.ncbi.nlm.nih. gov/BLAST/) to determine an approximate phylogenetic affiliation. Sequence similarity values between the isolate and related bacteria were evaluated using the Nucleotide Similarity Search program (http://147.47.212.35:8080; Chun et al., 2007) and sequences were aligned by using the CLUSTAL W software program (Thompson et al., 1994). Phylogenetic trees using the neighbour-joining and maximum-parsimony algorithms were constructed by the PHYLIP software (version 3.6; Felsenstein, 2002). The resulting tree topologies were evaluated using a bootstrap analysis based on 1000 resampled datasets with the PHYLIP package. Maximum-likelihood analysis was performed using RAxML-HPC in Abe (version 7.2.6) of the Cyberinfrastructure for Phylogenetic Research project (CIPRES, www.phylo.org; Stamatakis et al., 2005) at the San Diego Supercomputer Center.

Comparative analysis of the 16S rRNA gene sequences showed that strain $\mathrm{G} 3^{\mathrm{T}}$ was most closely related to $L$. mephitis B1953/27.1 ${ }^{\mathrm{T}}$ with $98.0 \%$ similarity and its $16 \mathrm{~S}$ rRNA gene sequence similarities with other related type species were less than $96.5 \%$. Phylogenetic analysis based on $16 \mathrm{~S}$ rRNA gene sequence indicated that strain $\mathrm{G} 3^{\mathrm{T}}$ formed a tight phylogenetic cluster with the type species of the genus Luteimonas, L. mephitis B1953/27.1 ${ }^{\mathrm{T}}$, within the genus Luteimonas with a $100 \%$ bootstrap value (Fig. 1). Analysis with the maximum-likelihood and maximumparsimony algorithms also showed that the strain formed a tight phylogenetic cluster with L. mephitis B1953/27.1 within the genus Luteimonas (Fig. 1).

DNA-DNA hybridization was carried out to evaluate the level of DNA relatedness between strain $\mathrm{G}^{\mathrm{T}}$ and L. mephitis KACC $11391^{\mathrm{T}}$ as described previously (Lee et al., 2011). Briefly, extracted genomic DNAs were fragmented with a HaeIII digestion and different amounts of the fragmented DNA were blotted onto Hybond-N + nylon membranes (Amersham Pharmacia Biotech) in three replicates after denaturation using $\mathrm{NaOH}$ solution and heating $\left(80^{\circ} \mathrm{C}\right)$. Each DNA $(4 \mu \mathrm{g})$ was used individually as a labelled DNA probe for cross-hybridization (Park et al., 2007). Random primed DNA labelling with digoxigenin (DIG)-dUTP and detection of hybrids by enzyme immunoassay on nylon membrane were performed using a DIG High Prime DNA Labelling kit (Roche Applied Science) according to the manufacturer's instructions and standard procedures (Sambrook \& Russell, 2001). The hybridization signals were captured and analysed with the Bio-Rad Quantity One software (version 4.62). The signal produced by hybridization

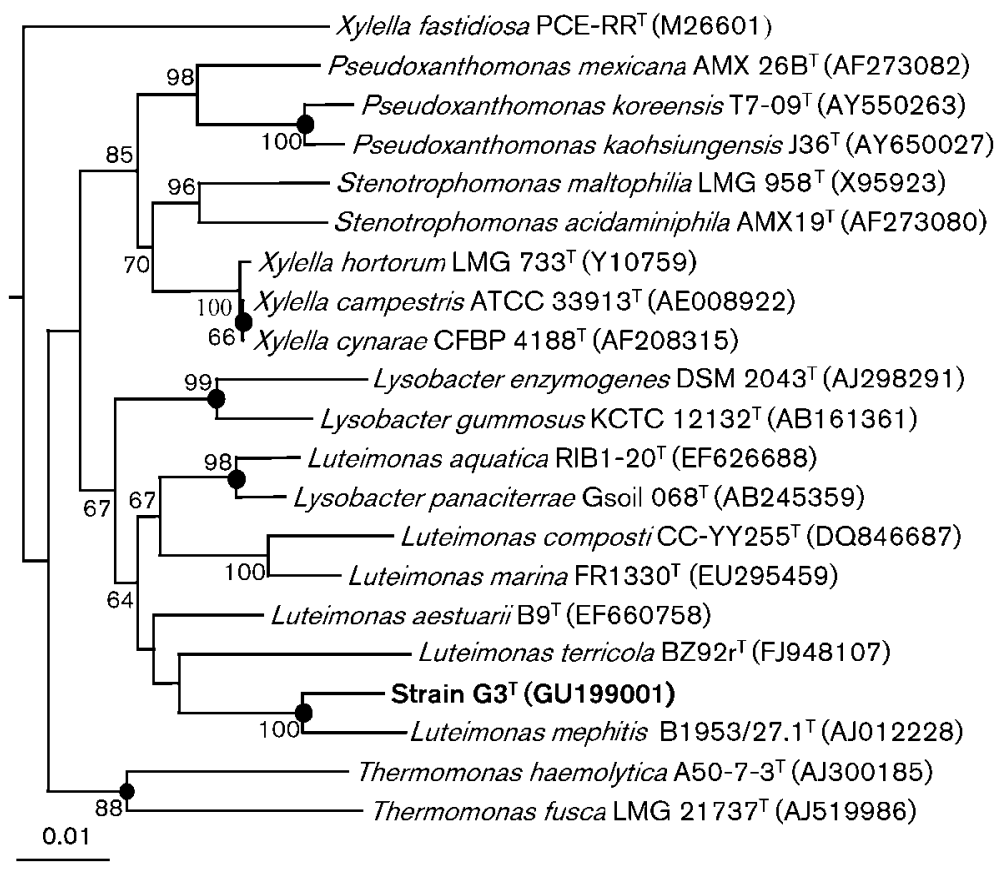
Fig. 1. Neighbour-joining tree based on $16 \mathrm{~S}$ rRNA gene sequences showing the phylogen- etic relationships of strain $\mathrm{G}^{\top}$ and related taxa. Bootstrap values are shown in percen- tages of 1000 replicates, when greater than $50 \%$. Filled circles indicate that the corres- ponding nodes were also recovered in trees generated with the maximum-parsimony and maximum-likelihood algorithms. Escherichia coli ATCC $11775^{\top}$ (X80725) was used as an outgroup (not shown). Scale bar, 0.01 changes per nucleotide position.


of the probe to the homologous target DNA was taken to be $100 \%$ and signal intensities by the self-hybridization of the series of dilutions were used for the calculation of the levels of DNA relatedness between strain $\mathrm{G} 3^{\mathrm{T}}$ and L. mephitis KACC $11391^{\mathrm{T}}$. The hybridization experiment was confirmed by cross-hybridization. The DNA G $+\mathrm{C}$ content of strain $\mathrm{G} 3^{\mathrm{T}}$ was determined by HPLC using a reversed-phase column (GROM-SIL 100 ODS-2FE; GROM) according to the method of Tamaoka \& Komagata (1984). The DNA-DNA relatedness value between strain $\mathrm{G} 3^{\mathrm{T}}$ and L. mephitis KACC $11391^{\mathrm{T}}$ was $35.2 \pm 3.3 \%$, which is clearly below the $70 \%$ threshold generally accepted for species delineation (Rosselló-Mora \& Amann, 2001). The DNA G + C content of strain $\mathrm{G}^{\mathrm{T}}$ was $69.6 \mathrm{~mol} \%$, which was within the range of 67-72 $\mathrm{mol} \%$ for the genus Luteimonas.

Growth was tested on R2A agar (Difco), laboratoryprepared Luria-Bertani (LB) agar, tryptic soy agar (TSA; Difco) and MA (Difco) at $30{ }^{\circ} \mathrm{C}$. Growth temperatures and $\mathrm{pH}$ values for growth of strain $\mathrm{G} 3^{\mathrm{T}}$ were examined by growing the isolate on MA agar at $5-45{ }^{\circ} \mathrm{C}$ at $5{ }^{\circ} \mathrm{C}$ intervals and in $\mathrm{MB}$ adjusted to $\mathrm{pH} 5.0-10.0$ at $0.5 \mathrm{pH}$ unit intervals. Media with different $\mathrm{pH}$ values were prepared using appropriate biological buffers: $\mathrm{Na}_{2} \mathrm{HPO}_{4} / \mathrm{NaH}_{2} \mathrm{PO}_{4}$ buffer,
$\mathrm{Na}_{2} \mathrm{CO}_{3} / \mathrm{NaHCO}_{3}$ buffer and $\mathrm{Na}_{2} \mathrm{HPO}_{4} / \mathrm{NaOH}$ buffer were used for $\mathrm{pH}$ values below 8.0, $\mathrm{pH}$ values of 8.0-10.0, and $\mathrm{pH} 10.0$, respectively (Gomori, 1955). The $\mathrm{pH}$ was confirmed and adjusted again after sterilization. Gram staining was performed using a bioMérieux Gram Stain kit according to the instructions of the manufacturer. Cell morphology and the presence of flagella were studied using phasecontrast microscopy and transmission electron microscopy (JEM-1010; JEOL) with 2-day-old cells grown on MA agar as described previously (Jeon et al., 2004). Requirement and tolerance of $\mathrm{NaCl}$ were determined in nutrient broth (NB: $3.0 \mathrm{~g}$ beef extract and $5.0 \mathrm{~g}$ peptone $\mathrm{l}^{-1}$ ) supplemented with modified artificial seawater (ASW: $0-10 \%$, w/v, NaCl at $1 \%$ intervals, $5.94 \mathrm{~g} \mathrm{MgSO}_{4} .7 \mathrm{H}_{2} \mathrm{O}, 4.53 \mathrm{~g} \mathrm{MgCl}_{2} \cdot 6 \mathrm{H}_{2} \mathrm{O}, 0.64 \mathrm{~g}$ $\mathrm{KCl}$ and $1.3 \mathrm{~g} \mathrm{CaCl}_{2} \mathrm{l}^{-1}$ ) (Kahng et al., 2009). Oxidase activity was tested by oxidation of $1 \%(w / v)$ tetramethylp-phenylenediamine (Merck), and catalase activity was evaluated by the production of oxygen bubbles in $3 \%$ (v/v) aqueous hydrogen peroxide solution (Smibert \& Krieg, 1994). Additional enzymic activities, biochemical features and the utilization of carbon source of strain $\mathrm{G} 3^{\mathrm{T}}$ and other reference Luteimonas species were determined by using the API ZYM kit, API 20NE kit (bioMérieux) and GN2 MicroPlate system (Biolog) according to the manufacturer's

Table 1. Phenotypic characteristics of strain $\mathrm{G} 3^{\top}$ and related Luteimonas species

Strains: 1, G3 $3^{\mathrm{T}}$ (this study); 2, L. mephitis KACC $11391^{\mathrm{T}}$ (Finkmann et al., 2000; Lipski \& Stackebrandt, 2005; Young et al., 2007); 3, L. aestuarii KCTC $22048^{\mathrm{T}}$ (Roh et al., 2008); 4, L. aquatica LMG $24212^{\mathrm{T}}$ (Chou et al., 2008). All strains were positive for the following characteristics (results from this study): hydrolysis of aesculin and gelatin, alkaline phosphatase, esterase (C4), esterase lipase (C8), leucine arylamidase, valine arylamidase, acid phosphatase and naphthol-AS-BI-phosphohydrolase. All of these strains were negative for Gram staining, nitrate reduction, indole production, acidification of glucose, arginine dihydrolase, hydrolysis of urea, $\beta$-glucuronidase, $\alpha$-mannosidase, $\alpha$-fucosidase and assimilation of L-arabinose, D-mannitol, potassium gluconate, capric acid, adipic acid, trisodium citrate and phenylacetic acid (all results from this study except Gram staining). + , Positive; -, negative; w, weakly positive.

\begin{tabular}{|c|c|c|c|c|}
\hline Characteristic & $1^{*}$ & 2 & 3 & 4 \\
\hline Isolation source & Tidal flat & Ammonia biofilter & Tidal flat & Fresh water \\
\hline Colony colour & Yellow to brown & Yellow & Yellow & Yellow \\
\hline $\mathrm{NaCl}$ range (\%) for growth & $0-9$ & $0-6^{*}$ & $0-3$ & $0-3$ \\
\hline \multicolumn{5}{|l|}{ Assimilation of (API 20NE)*: } \\
\hline D-Glucose & - & - & + & $\mathrm{w}$ \\
\hline Maltose & - & - & + & $\mathrm{w}$ \\
\hline Malic acid & - & - & + & + \\
\hline \multicolumn{5}{|l|}{ Enzyme activity (API ZYM)* } \\
\hline Lipase (C14) & + & + & - & - \\
\hline Trypsin & + & $\mathrm{W}$ & + & $\mathrm{W}$ \\
\hline$\alpha$-Galactosidase & - & $\mathrm{w}$ & - & - \\
\hline DNA G $+C$ content $(\mathrm{mol} \%)$ & 69.6 & 67.0 & 64.7 & 70.3 \\
\hline
\end{tabular}

${ }^{\star}$ These results were from this study $\left(30{ }^{\circ} \mathrm{C}\right)$. 
instructions, except that the inocula were prepared by suspending cells in $0.85 \%(\mathrm{w} / \mathrm{v})$ saline. Anaerobic growth was assessed on MA under anaerobic (with 4-10\% $\mathrm{CO}_{2}$ ) conditions using the GasPak Plus system (BBL) at $30{ }^{\circ} \mathrm{C}$ for 20 days.

Strain $\mathrm{G} 3{ }^{\mathrm{T}}$ grew well at $30{ }^{\circ} \mathrm{C}$ on R2A agar, LB agar, TSA and MA. When tested on MA, growth of strain $G 3^{T}$ was observed at temperatures between 15 and $40{ }^{\circ} \mathrm{C}$, with an optimum growth temperature of $30{ }^{\circ} \mathrm{C}$ and at the range of $\mathrm{pH}$ 5.5-9.0, with an optimum of $\mathrm{pH}$ 6.5-7.5. Strain $\mathrm{G} 3^{\mathrm{T}}$ grew in NB supplemented with modified ASW containing $0-9 \%(\mathrm{w} / \mathrm{v}) \mathrm{NaCl}$; optimal growth occurred in the range of $0-3 \% \mathrm{NaCl}$. Bacterial cells were Gram-negative, strictly aerobic, non-motile rods, $0.3-0.5 \mu \mathrm{m}$ wide and $0.7-1.2 \mu \mathrm{m}$ long (see Supplementary Fig. S1 in IJSEM Online). More physiological and biochemical characteristics of strain $\mathrm{G} 3^{\mathrm{T}}$ are described in Table 1 and in the species description. Some of them are in accordance with characteristics of members of the genus Luteimonas, whereas others allow the differentiation of strain $\mathrm{G}^{\mathrm{T}}$ from other Luteimonas species (Table 1).

Isoprenoid quinone was analysed by HPLC using a chromatograph (model LC-20A; Shimadzu) equipped with a diode array detector (SPD-M20A; Shimadzu) and a reversed-phase column ( 250 by $4.6 \mathrm{~mm}$; Kromasil, Akzo Nobel) as described previously (Komagata \& Suzuki, 1987). For analysis of fatty acid methyl esters, cells of strain $\mathrm{G} 3^{\mathrm{T}}$ and other reference Luteimonas species were harvested from TSA plates after incubation at $30{ }^{\circ} \mathrm{C}$ for 3 days. Analysis of fatty acid methyl esters was performed according to the instructions of the Microbial Identification System (MIDI; Microbial ID). The major respiratory lipoquinone detected in strain $\mathrm{G} 3^{\mathrm{T}}$ was ubiquinone-8 $(\mathrm{Q}-8)$. The major cellular fatty acids $\left(>10.0 \%\right.$ of the total fatty acids) of strain $\mathrm{G}^{\mathrm{T}}$ were iso- $\mathrm{C}_{15: 0}$, iso- $\mathrm{C}_{17: 1} \omega 9 \mathrm{c}$, iso- $\mathrm{C}_{16: 0}$ and iso- $\mathrm{C}_{11: 0}$. The overall fatty acid profile of strain $\mathrm{G}^{\mathrm{T}}$ was similar to those of other Luteimonas species, but the amounts of respective fatty acids, especially major cellular fatty acids, distinguished the strain from other Luteimonas species (Table 2). Therefore, the physiological, biochemical and phylogenetic properties of strain $G 3^{\mathrm{T}}$ support its description as a novel species within the genus Luteimonas for which the name Luteimonas lutimaris sp. nov. is proposed.

\section{Description of Luteimonas lutimaris sp. nov.}

Luteimonas lutimaris (lu.ti.mar'is. L. n. lutum mud; L. gen. n. maris of the sea; N.L. gen. n. lutimaris of sea mud).

Cells are Gram-staining-negative, strictly aerobic, nonmotile rods, $0.3-0.5 \mu \mathrm{m}$ wide and $0.7-1.2 \mu \mathrm{m}$ long. The colonies are yellow to brown, convex, round with entire margins on MA. Growth occurs at $15-40{ }^{\circ} \mathrm{C}$ (optimum $30{ }^{\circ} \mathrm{C}$ ), at $\mathrm{pH} 5.0-9.0$ (optimum $\mathrm{pH} 6.5-7.5$ ) and in the presence of $0-9.0 \%(\mathrm{w} / \mathrm{v}) \mathrm{NaCl}$ (optimum 0-3\%). Catalase- and oxidase-positive. In the API 20NE kit, negative for nitrate reduction, indole production, glucose acidification and arginine dihydrolase activities. Aesculin
Table 2. Cellular fatty acid composition (\%) of strain $\mathrm{G3}^{\top}$ and related Luteimonas species grown on TSA at $30{ }^{\circ} \mathrm{C}$ for 3 days

Strains: $1, \mathrm{G}^{\mathrm{T}}$; 2, L. mephitis KACC $11391^{\mathrm{T}}$; 3, L. aestuarii KCTC $22048^{\mathrm{T}}$; 4, L. aquatica LMG $24212^{\mathrm{T}}$. All data are from this study. Data are expressed as percentages of total fatty acids. Fatty acids amounting to less than $0.5 \%$ in all strains are not shown. Major components $(>10.0 \%)$ are highlighted in bold. tr, Trace amount $(<0.5 \%)$; , not detected.

\begin{tabular}{|c|c|c|c|c|}
\hline Fatty acid & 1 & 2 & 3 & 4 \\
\hline \multicolumn{5}{|c|}{ Saturated straight-chain } \\
\hline $\mathrm{C}_{14: 0}$ & 0.96 & 0.76 & 0.61 & $\operatorname{tr}$ \\
\hline $\mathrm{C}_{16: 0}$ & 3.81 & 1.17 & 2.01 & 5.69 \\
\hline \multicolumn{5}{|c|}{ Saturated branched } \\
\hline iso- $\mathrm{C}_{10: 0}$ & 0.52 & $\operatorname{tr}$ & $\operatorname{tr}$ & - \\
\hline iso- $\mathrm{C}_{11: 0}$ & 11.19 & 8.64 & 12.93 & 7.86 \\
\hline iso- $\mathrm{C}_{13: 0}$ & $\operatorname{tr}$ & 0.67 & $\operatorname{tr}$ & $\operatorname{tr}$ \\
\hline iso- $\mathrm{C}_{14: 0}$ & 1.20 & 2.14 & 0.52 & 0.54 \\
\hline iso- $\mathrm{C}_{15: 0}$ & 29.67 & 48.31 & 27.55 & 36.81 \\
\hline iso- $\mathrm{C}_{16: 0}$ & 11.59 & 5.09 & 5.65 & 2.93 \\
\hline iso- $\mathrm{C}_{17: 0}$ & 7.12 & 2.94 & 12.24 & 6.43 \\
\hline anteiso- $\mathrm{C}_{15: 0}$ & 1.92 & 3.56 & 5.86 & 2.80 \\
\hline anteiso- $\mathrm{C}_{17: 0}$ & $\operatorname{tr}$ & $\operatorname{tr}$ & 0.73 & $\operatorname{tr}$ \\
\hline \multicolumn{5}{|l|}{ Unsaturated } \\
\hline iso- $\mathrm{C}_{17: 1} \omega 9 c$ & 17.01 & 13.07 & 20.32 & 16.18 \\
\hline iso- $\mathrm{C}_{15: 1} \mathrm{~F}$ & 1.41 & 3.03 & - & 0.57 \\
\hline \multicolumn{5}{|l|}{ Hydroxy } \\
\hline $\mathrm{C}_{16: 0} 3-\mathrm{OH}$ & - & 0.68 & $\operatorname{tr}$ & - \\
\hline iso- $\mathrm{C}_{11: 0} 3-\mathrm{OH}$ & 8.07 & 6.36 & 7.09 & 10.27 \\
\hline iso- $\mathrm{C}_{12: 0} 3-\mathrm{OH}$ & 1.54 & $\operatorname{tr}$ & $\operatorname{tr}$ & $\operatorname{tr}$ \\
\hline iso- $\mathrm{C}_{17: 0} 3-\mathrm{OH}$ & - & $\operatorname{tr}$ & $\operatorname{tr}$ & 1.38 \\
\hline \multicolumn{5}{|c|}{ Summed features ${ }^{\star}$} \\
\hline 3 & 0.88 & 1.06 & 1.16 & 1.54 \\
\hline \multicolumn{5}{|l|}{ Unknown $\dagger$} \\
\hline ECL 11.799 & - & - & - & 3.18 \\
\hline ECL 14.263 & $\operatorname{tr}$ & - & $\operatorname{tr}$ & 0.93 \\
\hline
\end{tabular}

${ }^{\star}$ Summed features represent groups of two or three fatty acids that could not be separated by GLC with the MIDI system. Summed feature 3 contains $\mathrm{C}_{16: 1} \omega 7 c$ and/or $\mathrm{C}_{16: 1} \omega 6 c$.

$\dagger \mathrm{ECL}$, Equivalent chain-length.

and gelatin are hydrolysed. Urea is not hydrolysed. In the API ZYM kit, alkaline phosphatase, esterase (C4), esterase lipase (C8), lipase (C14), leucine arylamidase, valine arylamidase, cystine arylamidase, acid phosphatase and naphthol AS-BI-phosphohydrolase activities are present and weak enzymic activities are observed for trypsin, $\alpha$ chymotrypsin and $\beta$-glucuronidase, but $\alpha$-galactosidase, $\beta$-galactosidase, $\alpha$-glucosidase, $\beta$-glucosidase, $N$-acetyl $\beta$ glucosaminidase, $\alpha$-fucosidase and $\alpha$-mannosidase enzymic activities are absent. The carbon utilizations in the Biolog GN2 MicroPlate system are available in Supplementary Table S1 in IJSEM Online). The major isoprenoid quinone is Q-8. The major cellular fatty acids are iso- $\mathrm{C}_{15: 0}$, iso$\mathrm{C}_{17: 1} \omega 9 c$, iso- $\mathrm{C}_{16: 0}$ and iso- $\mathrm{C}_{11: 0}$. The DNA G $+\mathrm{C}$ content is $69.6 \mathrm{~mol} \%$ (HPLC). 
The type strain, G3 ${ }^{\mathrm{T}}\left(=\mathrm{KACC} 14929^{\mathrm{T}}=\mathrm{JCM} 16916^{\mathrm{T}}\right)$, was isolated from a tidal flat of the Taean coast in South Korea.

\section{Acknowledgements}

This research was supported by grants from the 21C Frontier Microbial Genomics and Application Center Program, Ministry of Education, Science \& Technology and the Technology Development Program for Agriculture and Forestry (TDPAF) of the Ministry for Agriculture, Forestry and Fisheries, Korea, and was supported by the Industry Academic Cooperation Foundation funded by CHA University.

\section{References}

Baik, K. S., Park, S. C., Kim, M. S., Kim, E. M., Park, C., Chun, J. \& Seong, C. N. (2008). Luteimonas marina sp. nov., isolated from seawater. Int J Syst Evol Microbiol 58, 2904-2908.

Chou, J.-H., Cho, N.-T., Arun, A. B., Young, C.-C. \& Chen, W.-M. (2008). Luteimonas aquatica sp. nov., isolated from fresh water from Southern Taiwan. Int J Syst Evol Microbiol 58, 2051-2055.

Chun, J., Lee, J. H., Jung, Y., Kim, M., Kim, S., Kim, B. K. \& Lim, Y. W. (2007). EzTaxon: a web-based tool for the identification of prokaryotes based on $16 \mathrm{~S}$ ribosomal RNA gene sequences. Int J Syst Evol Microbiol 57, 2259-2261.

Felsenstein, J. (2002). PHYLIP (phylogeny inference package), version 3.6a. Distributed by the author. Department of Genetics, University of Washington, Seattle, WA, USA.

Finkmann, W., Altendorf, K., Stackebrandt, E. \& Lipski, A. (2000). Characterization of $\mathrm{N}_{2} \mathrm{O}$-producing Xanthomonas-like isolates from biofilters as Stenotrophomonas nitritireducens sp. nov., Luteimonas mephitis gen. nov., sp. nov. and Pseudoxanthomonas broegbernensis gen. nov., sp. nov. Int J Syst Evol Microbiol 50, 273-282.

Gomori, G. (1955). Preparation of buffers for use in enzyme studies. Methods Enzymol 1, 138-146.

Jeon, C. O., Park, W., Ghiorse, W. C. \& Madsen, E. L. (2004) Polaromonas naphthalenivorans sp. nov., a naphthalene-degrading bacterium from naphthalene-contaminated sediment. Int J Syst Evol Microbiol 54, 93-97.

Kahng, H.-Y., Chung, B. S., Lee, D.-H., Jung, J.-S., Park, J. H. \& Jeon, C. O. (2009). Cellulophaga tyrosinoxydans sp. nov., a tyrosinaseproducing bacterium isolated from seawater. Int J Syst Evol Microbiol 59, 654-657.

Kim, J. M., Le, N. T., Chung, B. S., Park, J. H., Bae, J.-W., Madsen, E. L. \& Jeon, C. O. (2008). Influence of soil components on the biodegradation of benzene, toluene, ethylbenzene, and o-, m-, and p-xylenes by the newly isolated bacterium Pseudoxanthomonas spadix BD-a59. Appl Environ Microbiol 74, 7313-7320.

Kim, J. M., Lee, S. H., Jung, J. Y. \& Jeon, C. O. (2010a). Marinobacterium lutimaris sp. nov., isolated from a tidal flat. Int $J$ Syst Evol Microbiol 60, 1828-1831.

Kim, J. M., Lee, H. J., Kim, S. Y., Song, J. J., Park, W. J. \& Jeon, C. O. (2010b). Analysis of the fine-scale population structure of "Candidatus Accumulibacter phosphatis" in enhanced biological phosphorus removal sludge, using fluorescence in situ hybridization and flow cytometric sorting. Appl Environ Microbiol 72, 3825-3835.
Kim, J. M., Jung, J. Y., Chae, H. B., Park, W. \& Jeon, C. O. (2010c). Hwanghaeicola aestuarii gen. nov., sp. nov., a moderately halophilic bacterium isolated from a tidal flat of the Yellow Sea. Int J Syst Evol Microbiol 60, 2877-2881.

Komagata, K. \& Suzuki, K. (1987). Lipid and cell-wall analysis in bacterial systematics. Methods Microbiol 19, 161-207.

Lee, S. H., Shim, J. K., Kim, J. M., Choi, H.-K. \& Jeon, C. O. (2011). Henriciella litoralis sp. nov., isolated from a tidal flat, transfer of Maribaculum marinum Lai et al. 2009 to the genus Henriciella as Henriciella aquimarina nom. nov. and emended description of the genus Henriciella. Int J Syst Evol Microbiol 61, 722-727.

Lipski, A. \& Stackebrandt, E. (2005). Genus III. Luteimonas Finkmann, Altendorf, Stackebrandt and Lipski 2000, 280 ${ }^{\mathrm{VP}}$. In Bergey's Manual of Systematic Bacteriology, 2nd edn, vol. 2, part B, pp. 93-94. Edited by D. J. Brenner, N. R. Krieg, J. T. Staley \& G. M. Garrity. New York: Springer.

Lu, S., Park, M., Ro, H.-S., Lee, D. S., Park, W. \& Jeon, C. O. (2006). Analysis of microbial communities using culture-dependent and culture-independent approaches in an anaerobic/aerobic SBR reactor. J Microbiol 44, 155-161.

Park, M., Ryu, S. H., Vu, T. H., Ro, H. S., Yun, P. Y. \& Jeon, C. O. (2007). Flavobacterium defluvii sp. nov., isolated from activated sludge. Int J Syst Evol Microbiol 57, 233-237.

Roh, S. W., Kim, K.-H., Nam, Y.-D., Chang, H.-W., Kim, M.-S., Yoon, J.-H., Oh, H.-M. \& Bae, J.-W. (2008). Luteimonas aestuarii sp. nov., isolated from tidal flat sediment. J Microbiol 46, 525-529.

Rosselló-Mora, R. \& Amann, R. (2001). The species concept for prokaryotes. FEMS Microbiol Rev 25, 39-67.

Sambrook, J. \& Russell, D. W. (2001). Molecular Cloning: a Laboratory Manual, 3rd edn. Cold Spring Harbor, NY: Cold Spring Harbor Laboratory.

Smibert, R. M. \& Krieg, N. R. (1994). Phenotypic characterization. In Methods for General and Molecular Bacteriology, pp. 607-654. Edited by P. Gerhardt, R. G. E. Murray, W. A. Wood \& N. R. Krieg. Washington, DC: American Society for Microbiology.

Stamatakis, A., Ott, M. \& Ludwig, T. (2005). RAxML-OMP: an efficient program for phylogenetic inference on SMPs. In Proceedings of the 8th International Conference on Parallel Computing Technologies (PaCT2005), Lecture Notes in Computer Science 3506, 288-302. Springer Verlag.

Tamaoka, J. \& Komagata, K. (1984). Determination of DNA base composition by reversed-phase high-performance liquid chromatography. FEMS Microbiol Lett 25, 125-128.

Thompson, J. D., Higgins, D. G. \& Gibson, T. J. (1994). CLUSTAL W: improving the sensitivity of progressive multiple sequence alignment through sequence weighting, position-specific gap penalties and weight matrix choice. Nucleic Acids Res 22, 4673-4680.

Young, C.-C., Kämpfer, P., Chen, W.-M., Yen, W.-S., Arun, A. B., Lai, W.-A., Shen, F.-T., Rekha, P. D., Lin, K.-Y. \& Chou, J.-H. (2007). Luteimonas composti sp. nov., a moderately thermophilic bacterium isolated from food waste. Int J Syst Evol Microbiol 57, 741-744.

Zhang, D.-C., Liu, H.-C., Xin, Y.-H., Zhou, Y.-G., Schinner, F. \& Margesin, R. (2010). Luteimonas terricola sp. nov., a psychrophilic bacterium isolated from soil. Int J Syst Evol Microbiol 60, 15811584 . 